\title{
High cycle fatigue and fatigue crack propagation behaviors of $\beta$-annealed Ti-6Al-4V alloy
}

\author{
Daeho Jeong ${ }^{1}$, Yongnam Kwon², Masahiro Goto ${ }^{3}$ and Sangshik Kim ${ }^{1 *}$
}

\begin{abstract}
Background: The effect of $\beta$ annealing on high cycle fatigue (HCF) and fatigue crack propagation (FCP) behaviors of Ti64 alloy were examined, and the results were compared to those of mill-annealed counterpart.

Methods: The tensile tests, stress-controlled HCF tests, and FCP tests were conducted, and the fractographic and micrographic analyses were performed before and after the tests.

Results: The $\beta$-annealed Ti64 specimen showed inferior HCF properties as compared to the mill-annealed counterpart, as a result of lower yield strength. On the other hand the resistance to FCP of $\beta$-annealed Ti64 specimen was higher than that of mill-annealed counterpart in low and intermediate $\Delta \mathrm{K}$ regime.

Conclusions: Relatively easy fatigue crack initiation at the colony boundaries of $\beta$-annealed Ti64 specimen reduce the resistance to HCF. The resistance to FCP of $\beta$-annealed Ti64 specimen increased significantly particularly in low $\Delta K$ regime along with severe crack branching and deflection.
\end{abstract}

Keywords: High cycle fatigue, Fatigue crack propagation, Ti-6Al-4 V, Microstructure, Fatigue, $\beta$-annealing

\section{Background}

Today's high performance aircrafts, including engine power to weight ratios, airframe strength, aircraft speed and range, are largely attributable to the use of titanium alloys with high specific strength and fracture toughness (Ezugwu and Wang 1997; Andrade et al. 2010). The use of titanium alloys in airframe application has recently been growing as the use of CFRP (carbon fiber reinforced polymer) increases (Inagaki et al. 2014; Mrazova 2013). It is because designing joints between heterogeneous materials in an airframe must consider the prevention of galvanic corrosion and the elimination of strain caused by the difference in thermal expansion coefficients (Kaminaka et al. 2014; Donachie 2000).

A number of literatures have demonstrated that different heat treatment routes can produce a variety of microstructures in $\alpha+\beta$ Ti-6Al-4 V (Ti64) alloys, which strongly affects the static and dynamic properties (Venkatesh et al. 2009; Morita et al. 2005; Semiatin et al. 2003; Ivasishin et al. 2002; Chandler 1996). Typical heat treatment

\footnotetext{
* Correspondence: sang@gnu.ac.kr

${ }^{1}$ Department of Materials Engineering and Convergence Technology,

ReCAPT, Gyeongsang National University, Jinju 52828, South Korea

Full list of author information is available at the end of the article
}

processes of Ti64 alloy are conducted in $\alpha+\beta$ region below $\beta$ transus, including duplex annealing, solution heat treatment and aging (STA), recrystallization annealing, and mill annealing. Unlike the $\alpha+\beta$ processing, the $\beta$ annealing of $\alpha+\beta$ Ti64 alloy is a less common type of hot working (Chandler 1996; Campbell 2011). The purpose of $\beta$ annealing is to induce the microstructure of Widmanstatten or acicular $\alpha$ phase to obtain enhanced resistance to fracture, fatigue, and creep, albeit moderately sacrificing strength and ductility as compared to the microstructure of equiaxed $\alpha$ phase (Campbell 2011; Welsch et al. 1993; Wanhill and Barter 2011; Yoder et al. 1976). The $\beta$ annealing is done at a temperature only slightly higher than the $\beta$ transus to prevent excessive grain growth (Ivasishin et al. 2002). Annealing time depends on section thickness and should be long enough to permit complete transformation to $\beta$ phase, while it should also be held to a minimum to suppress the grain growth of $\beta$ phase (Donachie 2000; Ivasishin et al. 2002; Davis 1995; Borisova et al. 1975). The $\beta$ annealing can be followed by passive air cool, although larger sections may need to be fan cooled or even water quenched to prevent the formation of detrimental layer of 
$\alpha$ phase at grain boundaries (Donachie 2000). In $\alpha+\beta$ titanium alloys, thermal instability is a function of $\beta$ phase transformation since, cooling from the annealing temperature, the $\beta$ phase can transform to the undesirable (brittle) intermediate $\omega$ phase (Donachie 2000; Froes 2015; Rajan et al. 2011). To prevent the formation of $\omega$ phase, a stabilization anneal is generally given for the $\alpha+\beta$ titanium alloys (Donachie 2000; Froes 2015). This annealing treatment produces a stable $\beta$ phase capable of resisting further transformation when exposed to elevated temperatures in service. The $\alpha+\beta$ Ti64 alloy that is lean in $\beta$ can be air cooled from the annealing temperature without impairing their stability (Donachie 2000; Campbell 2008).

Despite the advantages of $\beta$-annealed Ti64 alloys, notably in the thick sections required for large primary aircraft structure, little is known in detail about fatigue properties. In this study, the high cycle fatigue (HCF) and fatigue crack propagation (FCP) behaviors of $\beta$-annealed Ti64 alloy were investigated, and the results were compared to those of mill-annealed Ti64 alloy. The effects of tensile properties and crack nucleation mechanism on the HCF behavior of $\beta$-annealed Ti64 was discussed based on the detailed fractographic and micrographic observation. The mechanisms associated with the microstructure-sensitive FCP behavior of $\beta$-annealed Ti64 alloy was also discussed with a particular emphasis placed on the morphology of crack path.

\section{Methods}

To study the HCF and FCP behaviors of $\beta$-annealed Ti64 alloy, $\beta$-annealed Ti64 plate with a thickness of $70 \mathrm{~mm}$ were supplied without $\beta$ stabilization after annealing. 3mm thick, mill-annealed Ti64 alloy was also provided to compare the present test results of $\beta$-annealed Ti64 alloy to the specimen with general purpose heat treatment. Figure 1 schematically describes the heat treatment conditions used in this study. For the micrographic observation, the Ti64 specimens were polished and etched using a solution of Kroll's reagent $(85 \mathrm{~mL} \mathrm{H} 2 \mathrm{O}+3 \mathrm{~mL} \mathrm{HNO} 3+$ $5 \mathrm{~mL} \mathrm{HF}$ ) (Gammon et al. 1985), and an optical microscope was utilized. Figure 2 shows the optical micrographs of (a) $\beta$-annealed and (b) mill-annealed Ti64 specimen. The $\beta$-annealed Ti64 specimen showed lamellar microstructure of the colonies of acicular $\alpha$ platelets aligned with the same crystallographic orientation within prior $\beta$ grain boundaries. Globular $\alpha$ phase and intergranular $\alpha$ layer along the $\beta$ grain boundary were intermittently observed. The mill-annealed Ti64 alloy showed the equiaxed $\alpha$ grains with an average size of $10 \mu \mathrm{m}$, and the particlelike transformed $\beta$ phase along $\alpha$ grain boundaries.

Flat tensile specimens and hour-glass typed, stresscontrolled (S-N) fatigue specimens were prepared from Ti64 plate with the tensile axis parallel to the longitudinal (L) direction. The compact tension (CT) specimens were also prepared form the plate with $\mathrm{L}$ (longitudinal) $-\mathrm{T}$

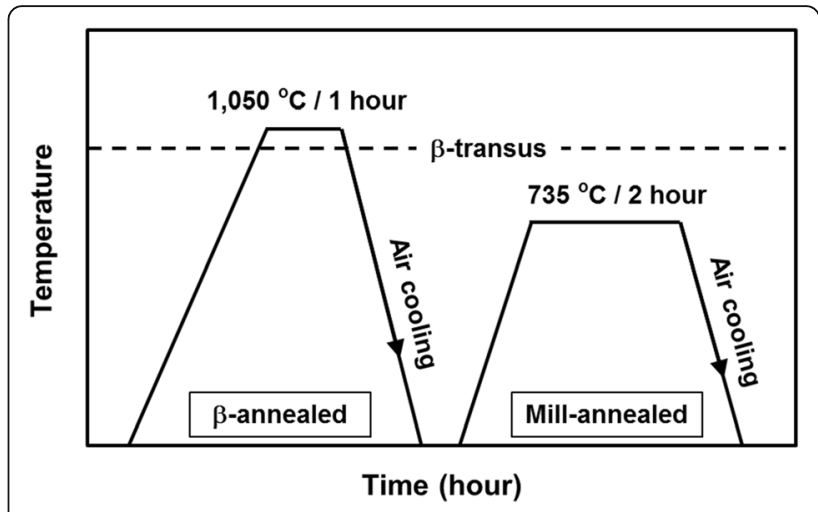

Fig. 1 The schematic illustration on the heat treatment conditions used in this study

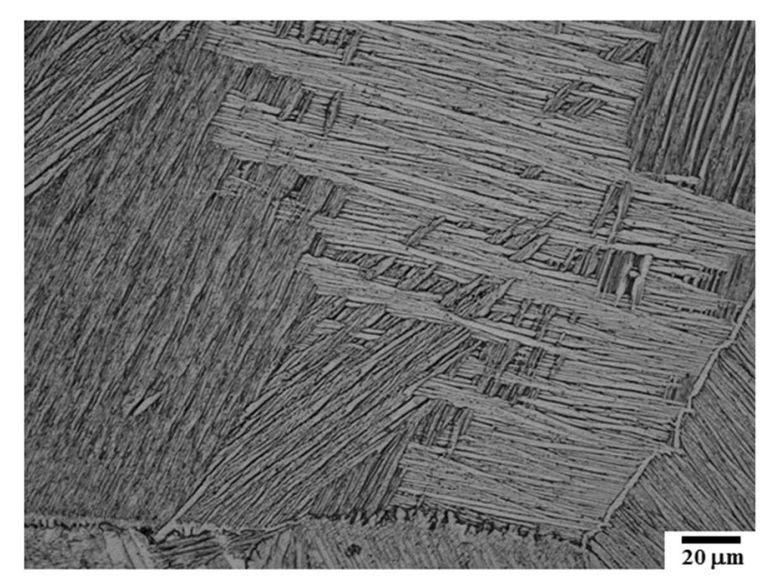

a

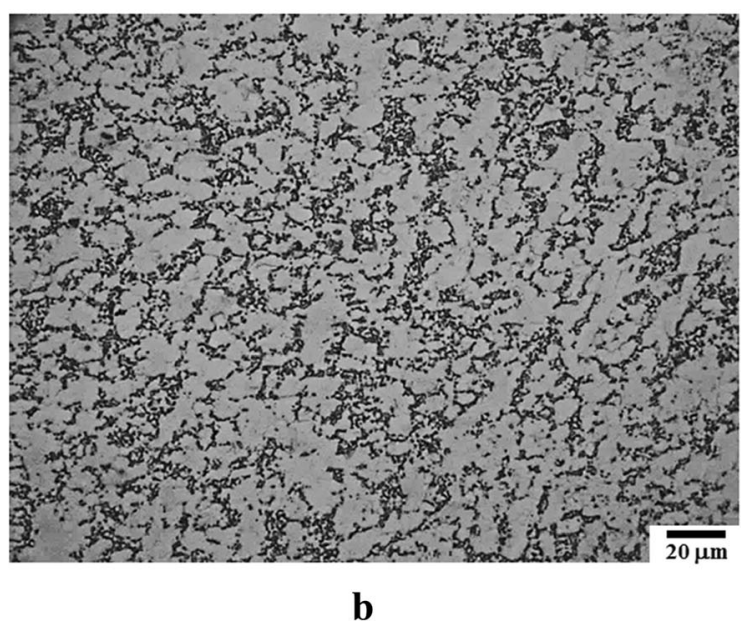

Fig. 2 The optical micrographs of (a) $\beta$-annealed, (b) mill-annealed Ti64 specimens 
(transverse) orientation. Figure 3 shows the schematic illustration of (a) tensile specimen, (b) S-N fatigue specimen, and (c) CT specimen used in this study. The tensile tests were performed on a screw-driven universal testing machine (model: MTDI UT-100) at a nominal strain rate of $1 \times 10^{-3} / \mathrm{sec}$. The S-N fatigue tests were conducted on a servo-hydraulic testing machine (model: Instron 8516) with the applied stresses ranging between 170 and $405 \mathrm{MPa}$ at an $R$ ratio of 0.1 under a uniaxial loading condition with a sinusoidal frequency of $30 \mathrm{~Hz}$ at $25^{\circ} \mathrm{C}$ in accordance with ASTM E466 (ASTM Standard E466 2002). The run-out of the S-N fatigue tests was defined as those not failed up to $5 \times 10^{6}$ cycles. The scanning electron microscope (SEM) analysis was conducted on the tensile and S-N fatigue tested specimens to examine the fracture mode. The fatigue crack propagation (FCP) tests were carried out on the CT specimens at $25{ }^{\circ} \mathrm{C}$ in accordance with ASTM E647 (ASTM Standard E647 2002) using a servo-hydraulic testing machine (model: Instron 8516). The FCP tests were performed with a sinusoidal frequency of $10 \mathrm{~Hz}$ and at the $R$ ratios of 0.1 and 0.7 . The fatigue crack length was automatically measured by using a DCPD (direct current potential drop) method. The fracture mode analysis and the crack path examination were conducted on the FCP

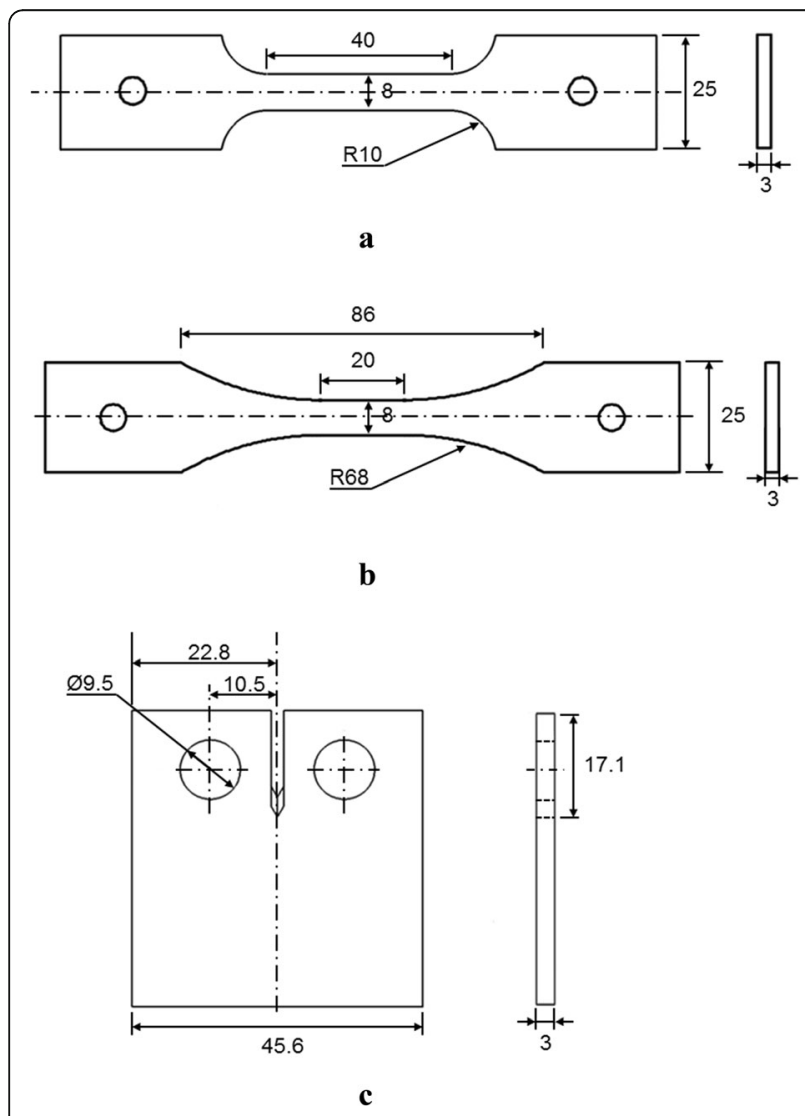

Fig. 3 The schematic illustration of (a) tensile specimen, (b) S-N fatigue specimen, and (c) compact tension (CT) specimen, used in this study tested specimens by using an SEM and an optical microscope.

\section{Results and discussion}

Figure 4 shows the typical stress-strain curves of $\beta$ annealed and mill-annealed Ti64 specimens with the loading axis parallel to the rolling direction. The test results are summarized in Table 1 , where each value represents the average of duplicate test results. As expected, both strength and ductility were lower for the $\beta$-annealed Ti64 specimen than the mill-annealed counterpart (Campbell 2011; Jeong et al. 2016a). It has been established that effective slip length is an important microstructural parameter affecting the tensile properties of $\alpha / \beta \mathrm{Ti}$ alloys. Primary $\alpha$ grain boundaries of mill-annealed Ti64 specimen, for example, act as barriers for dislocations to move, and smaller $\alpha$ grain size may reduce the effective slip length, enhancing both strength and ductility (Lütjering 1998; Ziaja et al. 2001). For the lamellar microstructure of acicular $\alpha$ phase, the aligned $\alpha$ platelets are separated by thin ribs of $\beta$ phase forming an $\alpha / \beta$ boundary which does not act as an effective barrier to slip. However, the colony of $\alpha$ platelets has a certain crystallographic orientation, and the colony boundaries are effective barriers to slip along with prior $\beta$ grain boundaries (Lütjering 1998; Ziaja et al. 2001; Lütjering and Williams 2013). The colony size, as well as prior $\beta$ grain size, therefore play an important role in determining the tensile properties of $\beta$-annealed Ti64 alloy (Lütjering 1998; Ziaja et al. $2001)$. The average colony size in the $\beta$-annealed Ti64 specimen was $84 \mu \mathrm{m}$, while the average $\alpha$ grain size was $10 \mu \mathrm{m}$ for the mill-annealed counterpart. Such a large difference in the effective slip length explained the inferior strength and ductility of $\beta$-annealed Ti64 specimen. Figure 5 shows the SEM fractographs of tensile-fractured (a) $\beta$-annealed and (b) mill-annealed Ti64 specimens. Large cleavage facets were observed for the $\beta$-annealed Ti64 specimen with

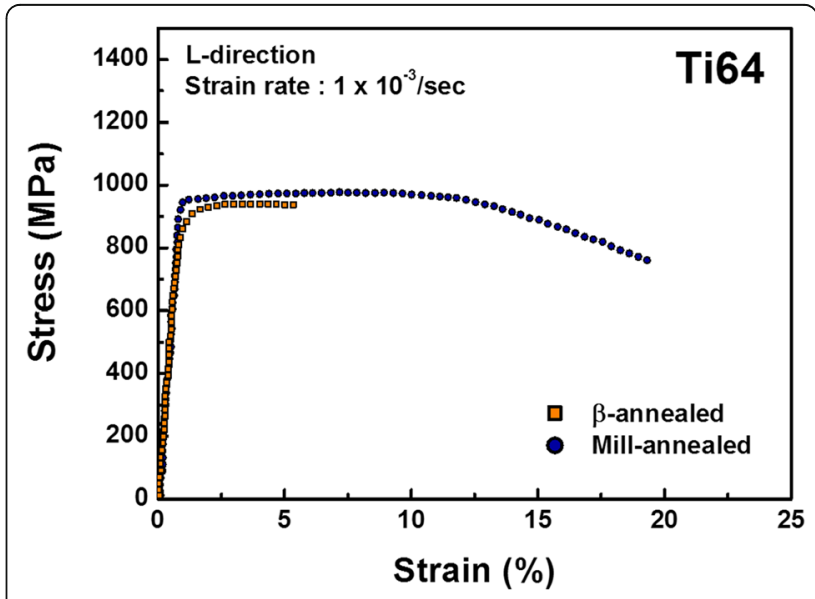

Fig. 4 The typical stress-strain curves of $\beta$-annealed and mill-annealed Ti64 specimens 
Table 1 The tensile properties of $\beta$-annealed and mill-annealed Ti64 specimens

\begin{tabular}{lllc}
\hline Heat treatment & $\begin{array}{l}\text { YS } \\
(\mathrm{MPa})\end{array}$ & $\begin{array}{l}\text { UTS } \\
(\mathrm{MPa})\end{array}$ & $\begin{array}{l}\text { Tensile } \\
\text { Elongation (\%) }\end{array}$ \\
\hline$\beta$-annealing & 867 & 950 & 4.2 \\
Mill-annealing & 953 & 979 & 18.0 \\
\hline
\end{tabular}

dimples intermittently located in between these facets. These cleavage facets appeared to be the result of tensile fracture occurring by cutting through the aligned $\alpha$ platelets. The plastic instability in between the facets were believed to induce dimpled rupture. Unlike the $\beta$-annealed Ti64 specimens, the mill-annealed counterpart showed a cup-and-cone type of ductile fracture with fine dimples covering the fracture surface.

The crack nucleation under fatigue loading largely determines the resistance to $\mathrm{HCF}$ of $\mathrm{Ti}$ alloys (Nicholas 2006). Since yield strength is the indicative of the resistance to slip deformation inducing crack nucleation on smooth surface, it is therefore one of the most important parameters affecting the HCF resistance (Jung et al. 2014; Jeong et al. 2013). As in the case of tensile behavior, the microstructure can have a significant influence on the HCF resistance of Ti64 alloy. For the mill-annealed Ti64 specimen, smaller primary $\alpha$ grain tends to improve the HCF resistance since yield strength increases with decreasing primary $\alpha$ grain size. Higher applied stress is then required to initiate a crack in primary $\alpha$ grain by slip band cracking (Lucas and Konieczny 1971; Bowen and Stubbington 1973). The smaller primary $\alpha$ grain also induces higher density of $\alpha / \alpha$ grain boundaries, which may increase the resistance to HCF by retarding the crack growth with the grain boundaries acting as microstructural barriers (Demulsant and
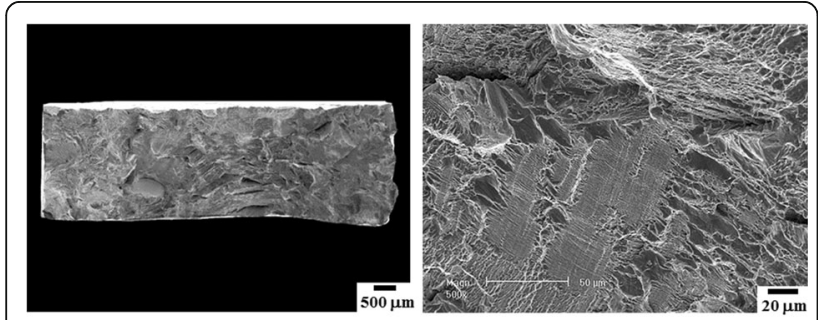

a

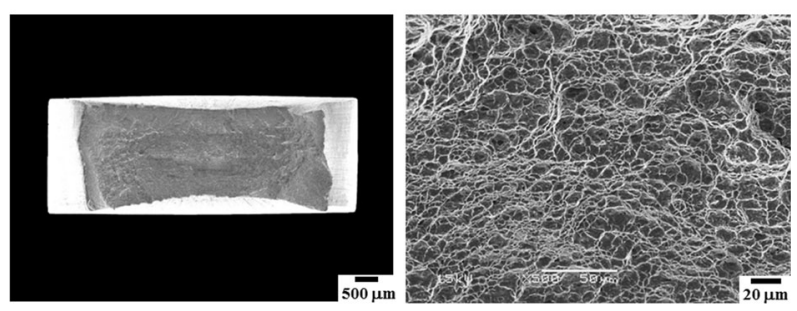

b

Fig. 5 The SEM fractographs of tensile-fractured (a) $\beta$-annealed and (b) mill-annealed Ti64 specimens
Mendez 1995). For the $\beta$-annealed Ti64 specimen, the microstructural factors affecting the HCF behavior include the sizes of colony, $\alpha$ platelet and prior $\beta$ grain. Smaller sizes of colony and prior $\beta$ grain in the $\beta$-annealed Ti64 specimen increase the resistance to HCF by reducing effective slip length, as in the mill-annealed counterpart (Lütjering 1998; Ziaja et al. 2001; Lucas and Konieczny 1971; Bowen and Stubbington 1973; Demulsant and Mendez 1995). The narrower aligned $\alpha$ platelets within colonies can further suppress the crack initiation by slip band cracking, since the crack needs to cross through more of the $\beta$ ribs in the aligned $\alpha$ platelets (Eylon and Pierce 1976; Bania et al. 1982; Ruppen et al. 1979). As in the mill-annealed Ti64 specimen, colony boundaries and prior $\beta$ grain boundaries in the $\beta$-annealed specimen can act as microstructural barriers for crack to grow, improving the resistance to HCF.

Figure 6a shows the S-N fatigue curves of $\beta$-annealed and mill-annealed Ti64 specimens, uniaxially fatigued at

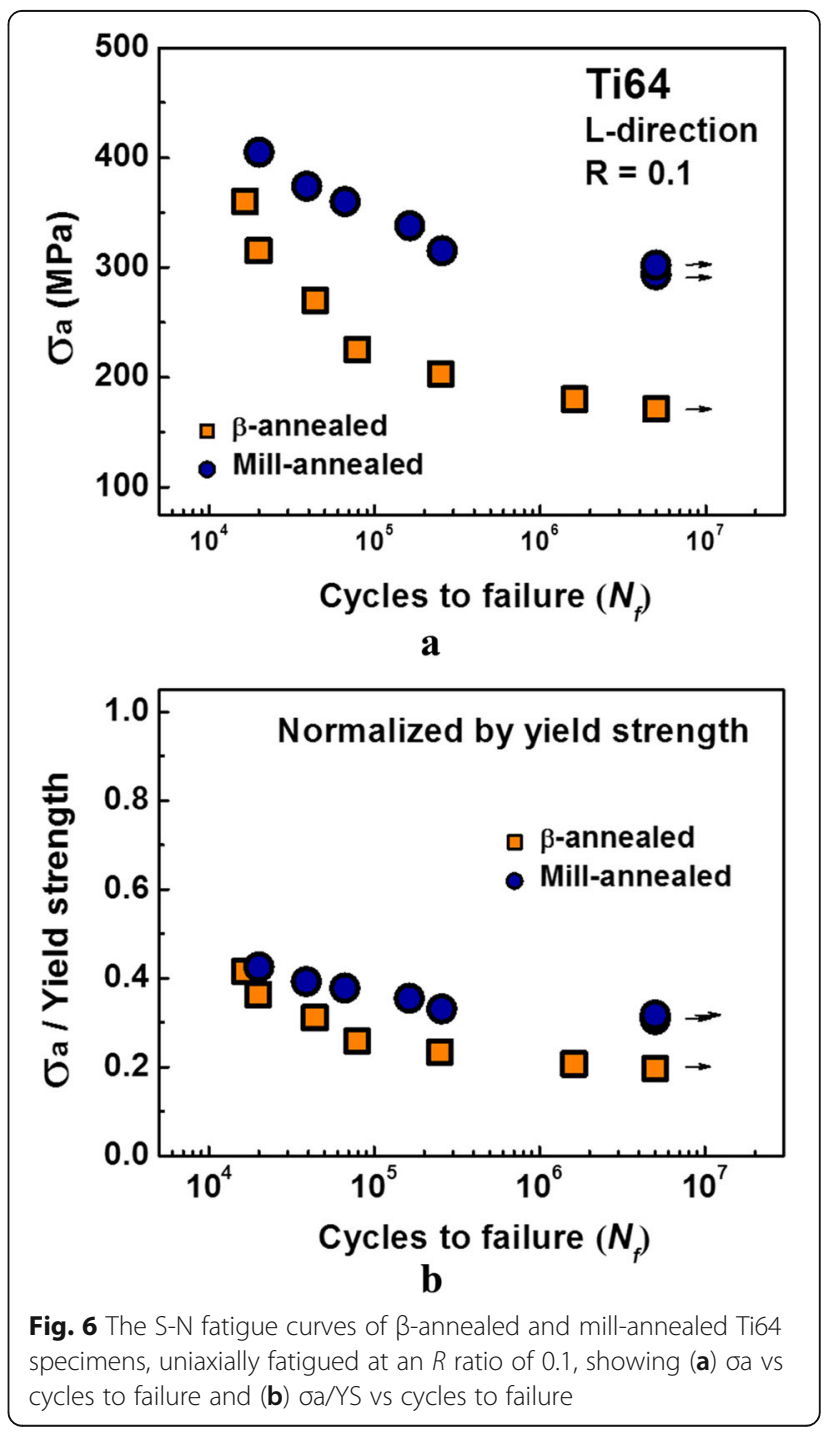


an $R$ ratio of 0.1 . This figure clearly shows that the resistance to S-N fatigue of $\beta$-annealed Ti64 was inferior to that of mill-annealed counterpart. As mentioned previously, such a trend in Fig. 6a can be mostly due to lower yield strength of $\beta$-annealed Ti64 alloy as compared to the mill-annealed counterpart. To confirm such a notion, the S-N fatigue curves of $\beta$-annealed and millannealed Ti64 specimens were normalized by the yield strength values. As shown in Fig. $6 \mathrm{~b}$, two fatigue curves became closely merged, suggesting that the yield strength played an important role in determining the HCF behavior of Ti64 alloy. It was also notable in Fig. $6 \mathrm{~b}$ that there existed considerable difference between two normalized fatigue curves. It was therefore suggested that, the microstructural characteristics, as well as yield strength, may influence the HCF resistance of Ti64 specimen by affecting fatigue crack nucleation. The fatigue cracks in $\alpha+\beta \mathrm{Ti}$ alloys tend to initiate in slip bands at the surface of large $\alpha$ grain in an early stage of fatigue life (Kim et al. 2013; Sung et al. 2016). Under an applied stress level close to fatigue limit, it has been reported that crack starts to form at the interface between $\alpha$ and $\beta$ phases later in the fatigue life (Hines and Lütjering 1999). Figure 7 shows the micrographic examination of crack nucleation on the etched specimen's surface and the matching SEM fractographs for the mill-annealed Ti64 specimen fatigued at an $R$ ratio of 0.1. Basically, two different types of crack initiation were observed, including (a) an intragranular cracking within $\alpha$ grain, and (b) a cracking at $\alpha / \beta$ boundary. The present observation in Fig. 7 matched to the previously reported nucleation sites of fatigue crack nucleation in mill-annealed Ti64 alloys (Jeong et al. 2016a). The matching SEM fractographs
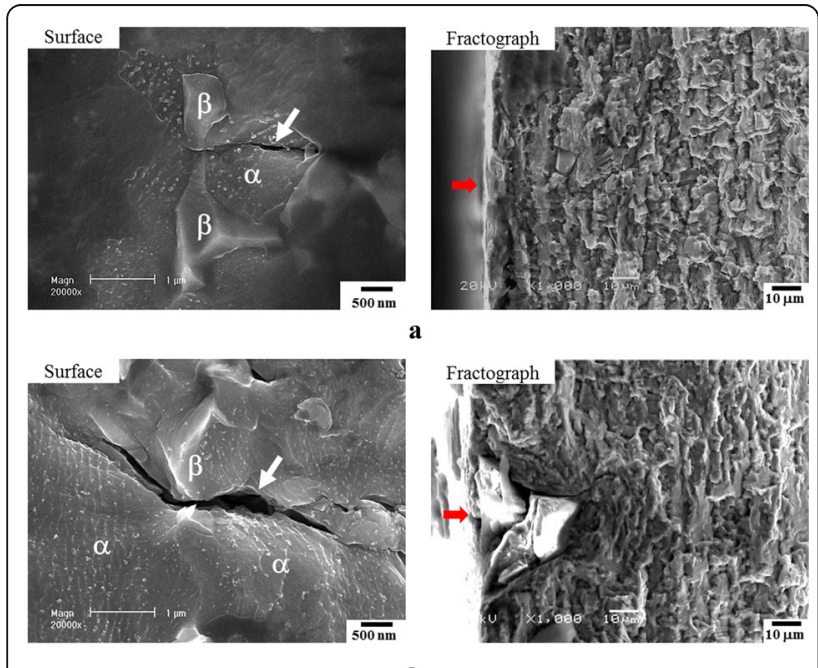

b

Fig. 7 The SEM micrographic observation of fatigue-tested mill-annealed Ti64 specimen, and the matching SEM fractographs, showing (a) an intragranular cracking within a grain and (b) a cracking at $\alpha / \beta$ boundary reflected the nature of crack nucleation site, showing particle-like $\beta$ phase on the fracture surface for the cracking case at $\alpha / \beta$ boundary. In general, coarse lamellar microstructures with colonies of aligned $\alpha$ and extended planar slip across these colonies often have lower resistance to HCF as compared to the microstructure of finegrained equiaxed $\alpha$ phase with the reduced effective slip lengths (Lütjering 1998; Ziaja et al. 2001). To better understand the HCF behavior of $\beta$-annealed Ti64 alloy, the preferential sites for crack nucleation and the fracture mode were examined in the fatigue-failed specimen. Figure 8 shows the specimen's surface showing the crack initiation and the SEM fractographs of fatigue-tested $\beta$ annealed Ti64 specimen. Unlike mill-annealed counterparts, the fatigue cracks in the $\beta$-annealed Ti64 specimen were formed along the colony boundaries. Once a small crack was initiated at the $\alpha / \beta$ interface by slip band cracking, the crack tended to propagate in a brittle cleavage manner forming large facets on the fracture surface. Considering the pseudo-cleavage nature of crack growth for the mill-annealed Ti64 specimen (Fig. 7), substantial difference in crack growth between two annealing conditions was expected. The present fractographic and micrographic examinations in Figs. 7 and 8 suggested that the ease of crack nucleation, as well as the lower yield strength, contributed to the inferior resistance to HCF of $\beta$-annealed Ti64 specimen as compared to the mill-annealed counterpart. It was clearly noted that the lamellar structure in $\beta$ -

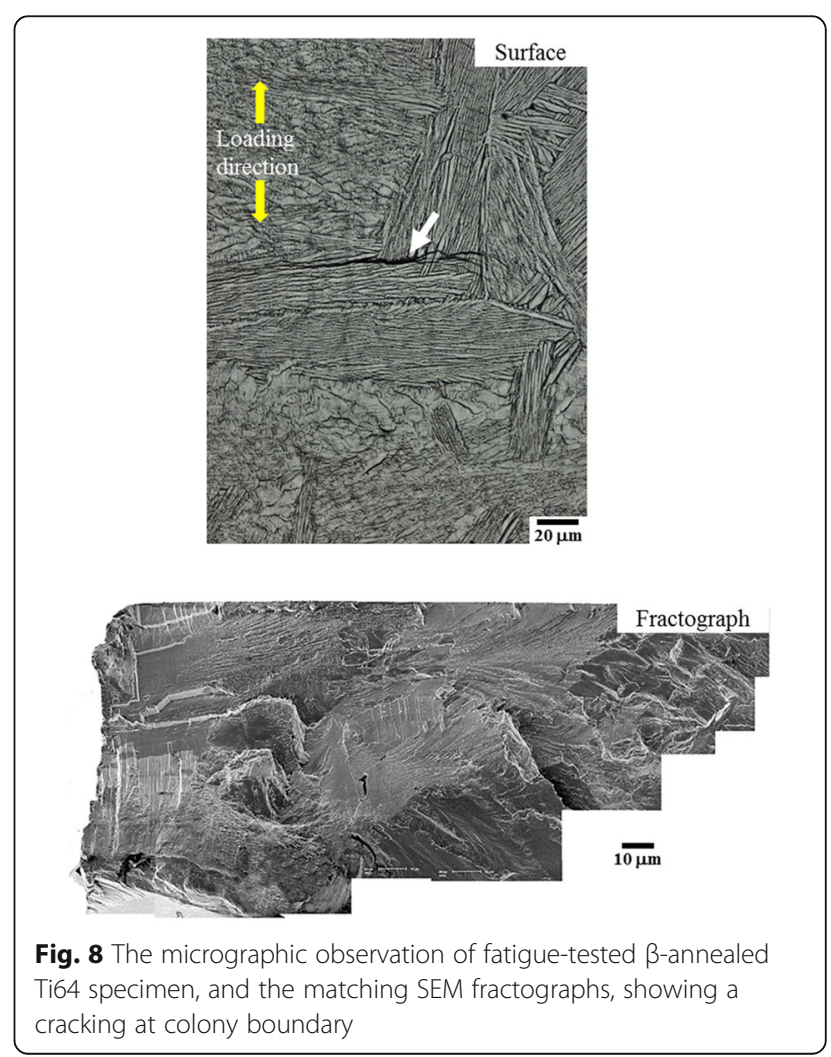


annealed Ti64 specimens led to easy crack initiation by slip band cracking along $\alpha / \beta$ interface as compared to quasi-cleavage cracking in $\alpha$ grain or $\alpha /$ particle-like $\beta$ interface for the mill-annealed counterpart.

Figure 9 shows the $\mathrm{da} / \mathrm{dN}-\Delta \mathrm{K}$ curves of $\beta$-annealed and mill-annealed Ti64 specimens, FCP-tested at an $R$ ratio of (a) 0.1 and (b) 0.7. It was noted that the FCP rates of $\beta$-annealed Ti64 specimen were substantially lower than those of mill-annealed counterpart at low and intermediate $\Delta \mathrm{K}$ regimes at both $R$ ratios of 0.1 and 0.7 . Above the $\Delta \mathrm{K}$ value of $30 \mathrm{MPa} \sqrt{\mathrm{m}}$ at an $R$ ratio of 0.1 and $10 \mathrm{MPa} \sqrt{\mathrm{m}}$ at an $R$ ratio of 0.7 , the FCP rates of $\beta$-annealed and mill-annealed specimens became similar with each other. As expected, the increase in $R$ ratio from 0.1 to 0.7 increased the FCP rates of each specimen, particularly in low $\Delta \mathrm{K}$ regime. The effect of $\mathrm{R}$ ratio on the FCP behavior is mainly attributed to crack closure effects, in which crack faces contact each other with the crack closure stress intensity factor, $K_{\mathrm{cl}}$ lower than the minimum applied stress intensity factor, $K_{\min }$ (Starke and Williams 1989; Jeong et al. 2015a). It was noted in Fig. 9 that the difference in the FCP rates of Ti64 specimens between $\beta$-annealing and mill-annealing in low $\Delta \mathrm{K}$ regime tended to decrease with increasing $R$ ratio from 0.1 to 0.7 . In order to understand the reason for the improved resistance to FCP with $\beta$-annealing at low and intermediate $\Delta \mathrm{K}$ regimes, the crack path was examined by using an optical microscope. For this examination, selected specimens were polished, etched, FCP tested, and the crack paths were photo-documented. Figure 10 shows the crack paths of $\beta$-annealed Ti64 specimen, FCP tested at an $R$ ratio of 0.1 and documented at (a) $\Delta \mathrm{K}_{\text {th }}$ regime, (b) the $\Delta \mathrm{K}$ of $20 \mathrm{MPa} \sqrt{\mathrm{m}}$, and (c) the $\Delta \mathrm{K}$ of $40 \mathrm{MPa} \sqrt{\mathrm{m}}$. For comparison, the crack path of mill-annealed Ti64 specimen examined at $\Delta K_{\text {th }}$ regime is included in Fig. 10d. A number of bifurcated cracks were observed for the $\beta$ annealed Ti64 specimen at low and intermediate $\Delta \mathrm{K}$ regime. The bifurcated cracks mostly cut through the packets of $\alpha$ colonies. When cracks were favorably oriented relative to the microstructural orientation (i.e., packet orientation, grain boundary orientation), some cracks grew following prior $\beta$ grain boundaries or packet boundaries. The mill-annealed Ti64 specimen with equiaxed $\alpha$ grains, on the other hand, did not show any notable crack bifurcation, regardless of applied $\Delta \mathrm{K}$. It was notable that the crack bifurcation in the $\beta$-annealed Ti64 specimen was no longer observed at high $\Delta \mathrm{K}$ regime, as shown in Fig. 10c. The fatigue crack growth of $\alpha+\beta \mathrm{Ti}$ alloys into adjoining, but differently oriented, $\alpha$ colonies has been known to involve significant crack deflection, crack bifurcation, and secondary crack formation, because of the limited number of slip systems available within hcp $\alpha$ phase (Halliday and Beevers 1981; Hicks et al. 1983; Suresh 1983; Suresh 1985; Suresh and Ritchie 1982). The
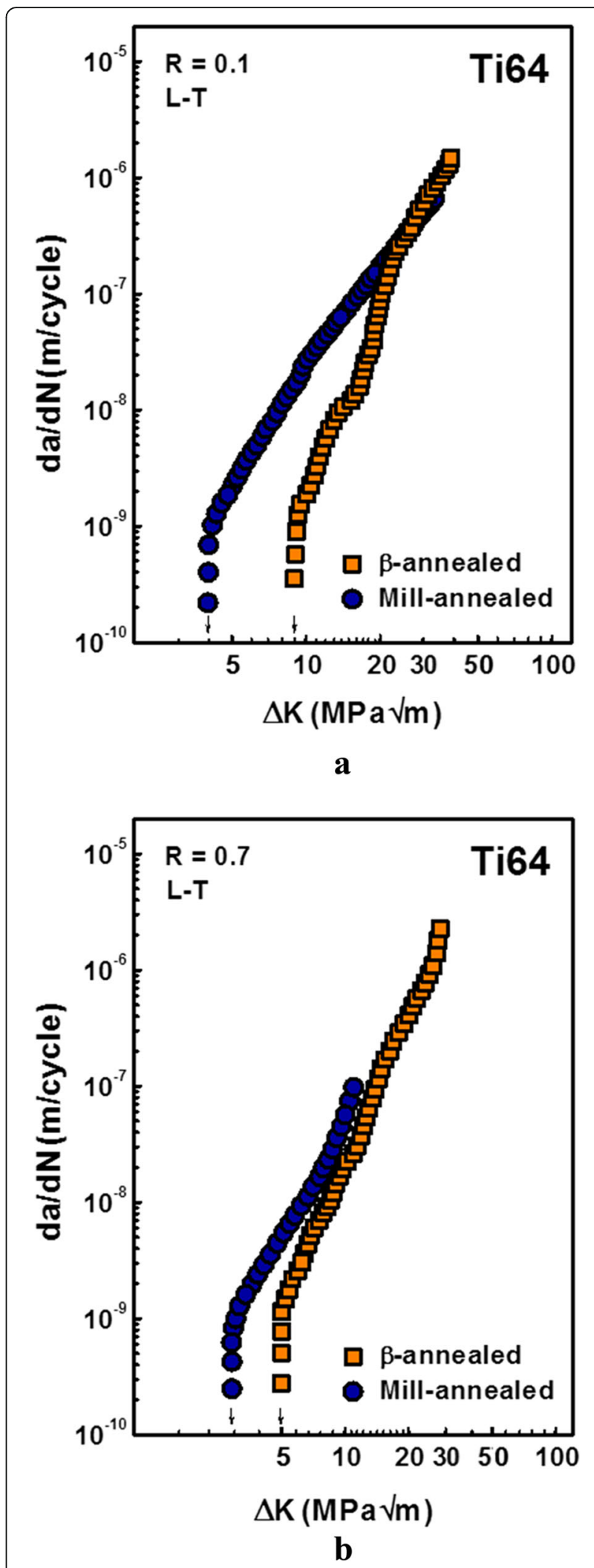

Fig. 9 The $d a / d N-\Delta K$ curves of $\beta$-annealed and mill-annealed Ti64 specimens, FCP tested at an $R$ ratio of (a) 0.1 and (b) 0.7 


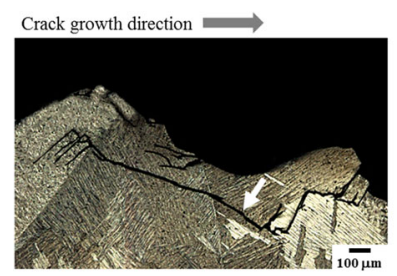

$\mathbf{a}$

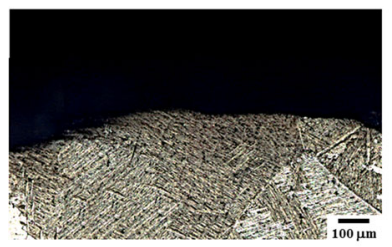

c

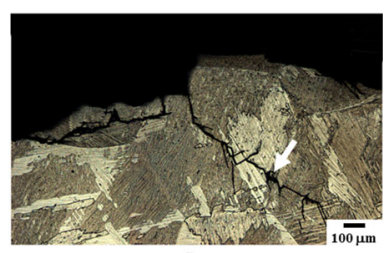

b

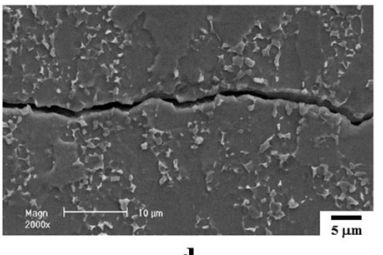

d
Fig. 10 The crack paths of $\beta$-annealed Ti64 specimen, FCP tested at an $R$ ratio of 0.1 and documented at (a) $\Delta K_{\text {th }}$ regime, (b) the $\Delta K$ of $20 \mathrm{MPa} \sqrt{\mathrm{m}}$ and $(\mathbf{c})$ the $\Delta \mathrm{K}$ of $40 \mathrm{MPa} \sqrt{\mathrm{m}}$ by using an optical microscope. For comparison, (d) the crack path of mill-annealed Ti64 specimen examined by using an SEM at $\Delta \mathrm{K}_{\text {th }}$ regime is also included

present observation confirmed that the lamellar structure encouraged the crack bifurcation at low and intermediate $\Delta \mathrm{K}$ regime, which in turn reduced the effective $\Delta \mathrm{K}$ value and eventually decreased the FCP rates. The crack closure would be higher for the microstructure with bifurcated crack, further reducing the FCP rates particularly at low $\Delta \mathrm{K}$ regime. The superior crack growth resistance of $\beta$ annealed Ti64 specimens with the lamellar microstructure of $\alpha$ colony is therefore attributable to a crack path characterized by high degree of crack deflection, bifurcation and secondary cracking. Figure 11 shows the crack paths of $\beta$-annealed Ti64 specimen, FCP tested at an $R$ ratio of 0.7 and documented at (a) $\Delta \mathrm{K}_{\text {th }}$ regime and (b) the $\Delta \mathrm{K}$ of $40 \mathrm{MPa} \sqrt{\mathrm{m}}$. It was notable at high $R$ ratio of 0.7 that the crack bifurcation and deflection were no longer observed even at low $\Delta \mathrm{K}$ regime. No crack meandering by bifurcation and deflection appeared to be responsible for the less notable improvement in the resistance to FCP at an $R$ ratio of 0.7 with the $\beta$-annealing as compared to that at $R$ ratio of 0.1 . The present observation also suggested there exists a critical $K_{\max }$ value over which the crack bifurcation no longer occur in the $\beta$-annealed Ti64 specimen.

Figures 12 and 13 show the SEM fractographs of FCPtested $\beta$-annealed Ti64 specimen, documented (a) in the near-threshold $\Delta \mathrm{K}$ regime and (b) at the $\Delta \mathrm{K}$ of $30 \mathrm{MPa} \sqrt{\mathrm{m}}$, respectively, at an $R$ ratio of 0.1 (Fig. 12) and 0.7 (Fig. 13). Previous studies by the authors on the FCP behavior of mill-annealed Ti64 specimen showed fine transgranular facets by quasi-cleavage in the near-threshold $\Delta \mathrm{K}$ regime (Jeong et al. 2016b). With increasing $\Delta \mathrm{K}$, quasi-cleavage transgranular facets became finer. For the $\beta$-annealed Ti64 specimen, large transgranular cleavage facets were observed in near-threshold $\Delta \mathrm{K}$ regime. Considering the

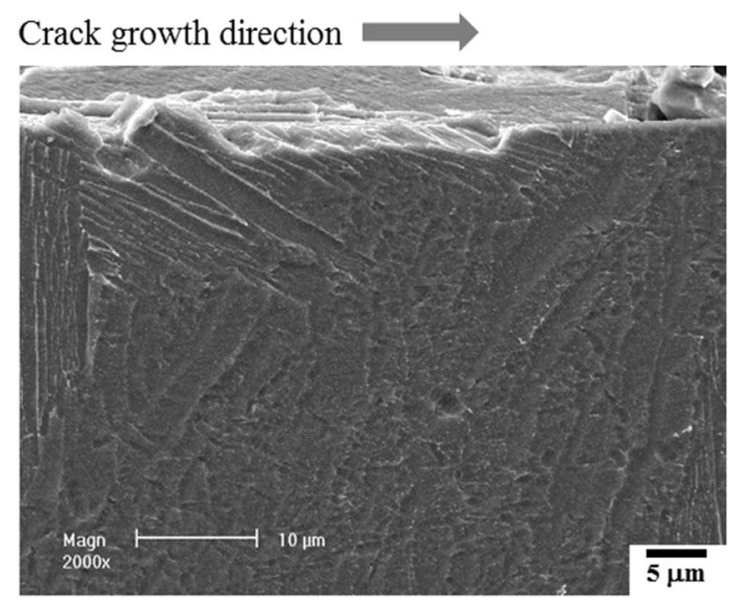

$\mathbf{a}$

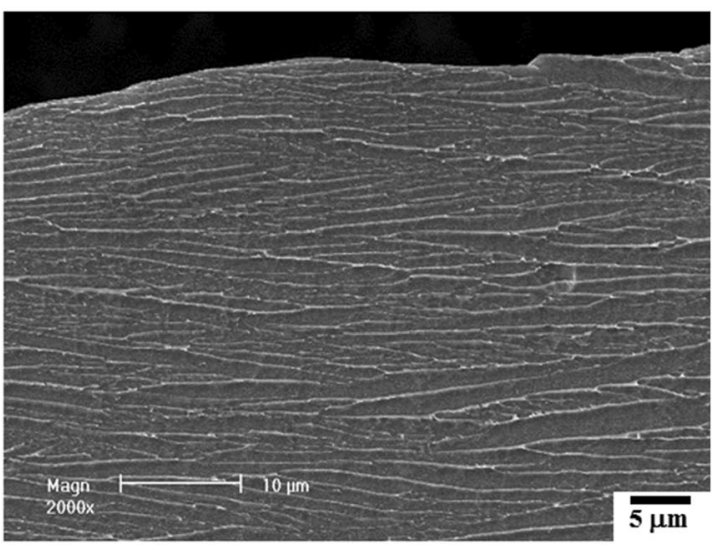

b

Fig. 11 The crack paths of $\beta$-annealed Ti64 specimen, FCP tested at an $R$ ratio of 0.7 and documented at (a) $\Delta K_{\text {th }}$ regime and (b) the $\Delta \mathrm{K}$ of $40 \mathrm{MPa} \sqrt{\mathrm{m}}$

size of each facet it was suggested that both colony boundaries and $\beta$ grain boundaries affected the FCP behavior of $\beta$-annealed Ti64 specimen (Kim et al. 2011; Jeong et al. 2015b; Jeong et al. 2014). With increasing $\Delta \mathrm{K}$, quasicleavage faceting became dominant for the $\beta$-annealed specimen. Due to the crack branching, secondary cracks were intermittently observed on the fracture surface. Basically, the trend observed at an $R$ ratio of 0.1 in Fig. 12 for the $\beta$-annealed Ti64 specimen also prevailed at high $R$ ratio of 0.7 , showing large transgranular facets on the fracture surface.

\section{Conclusions}

The high cycle fatigue (HCF) and fatigue crack propagation (FCP) behaviors of $\beta$-annealed Ti64 alloy were studied, and the following conclusions are drawn. 


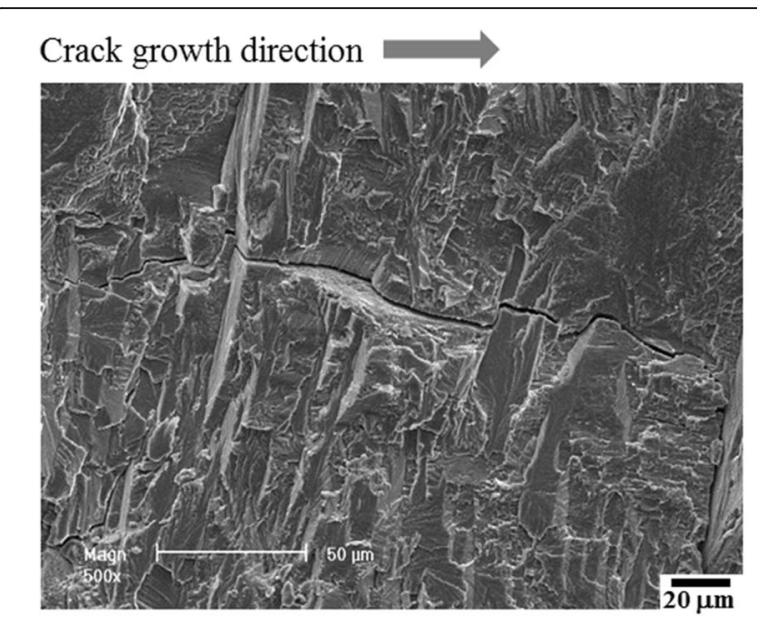

a

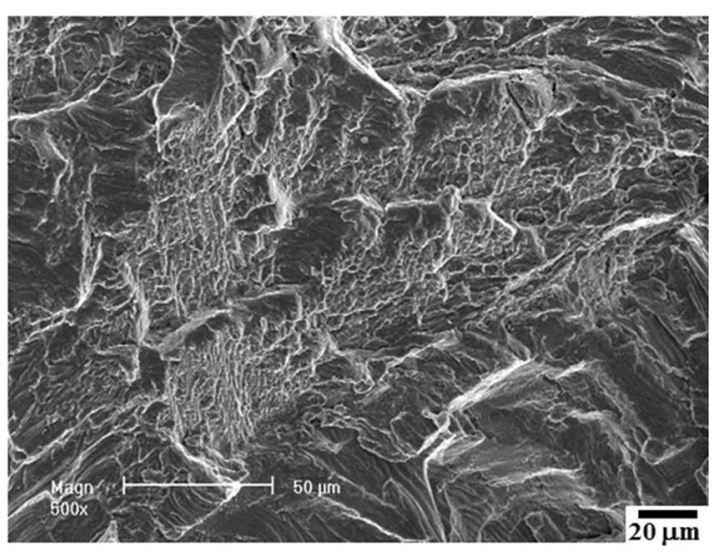

b

Fig. 12 The SEM fractographs of $\beta$-annealed Ti64 specimen, FCP tested at an $R$ ratio of 0.1 and documented at (a) $\Delta K_{\text {th }}$ regime and (b) the $\Delta \mathrm{K}$ of $30 \mathrm{MPa} \sqrt{\mathrm{m}}$

1. The $\beta$-annealed Ti64 specimen showed inferior tensile properties as compared to the mill-annealed counterpart. The decrease in tensile strength and ductility with $\beta$-annealing was related to the increase in the effective slip length as colony boundaries, as well as prior $\beta$ grain boundaries, acted as microstructural barriers for dislocation movement.

2. Along with the reduced yield strength with $\beta$-annealing, the resistance to HCF of $\beta$-annealed Ti64 specimen was also lower than that of mill-annealed counterpart. Relatively easy fatigue crack initiation at the colony boundaries of $\beta$-annealed Ti64 specimen, as compared to the initiation either at $\alpha / \beta$ interface or within $\alpha$ grain for the mill-annealed counterpart, further reduce the resistance to HCF.

3. Due to the extrinsic effect of crack branching and deflection, the resistance to FCP of $\beta$-annealed Ti64 specimen was higher than that of mill-annealed

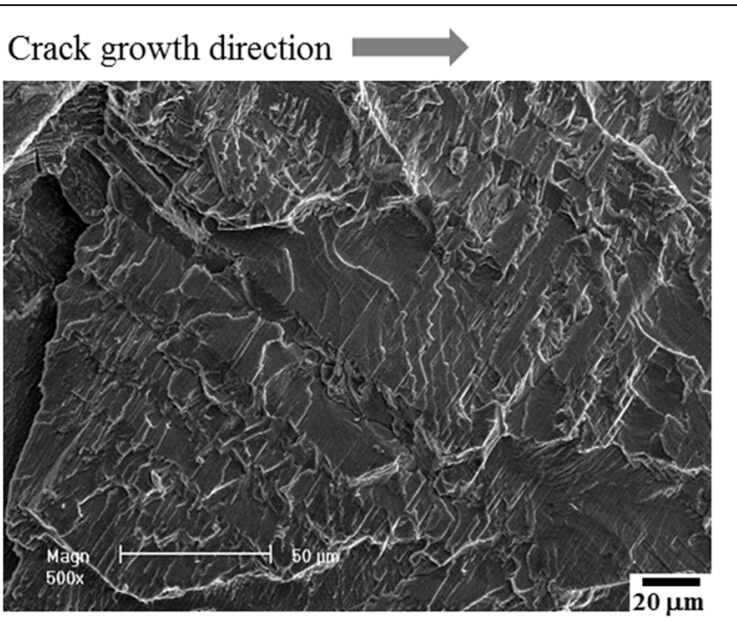

$\mathbf{a}$

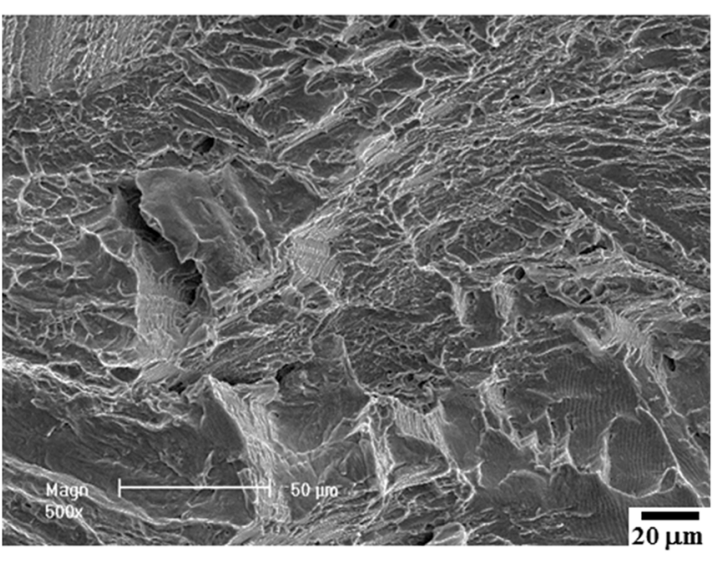

b

Fig. 13 The SEM fractographs of $\beta$-annealed Ti64 specimen, FCP tested at an $R$ ratio of 0.7 and documented at (a) $\Delta \mathrm{K}_{\text {th }}$ regime and (b) the $\Delta \mathrm{K}$ of $30 \mathrm{MPa} \sqrt{\mathrm{m}}$

counterpart in low and intermediate $\Delta \mathrm{K}$ regime at both $R$ ratios of 0.1 and 0.7 . At high $\Delta \mathrm{K}$ regime, the crack branching and deflection was no longer observed, and the FCP rates of $\beta$-annealed Ti64 specimen became similar to those of mill-annealed counterpart.

\section{Acknowledgements}

This work has been supported by the Engineering Research Center (ERC) Program through the National Research Foundation of Korea (NRF) funded by the Ministry of Education, Science and Technology (2011-0030801). This work was also supported by the Industrial Technology Innovation Program (10050561, Forming, Post-treatment and Assembly Manufacturing Technology for Nozzle Fairing of 17700 lbs Supersonic Engine) funded By the Ministry of Trade, Industry and Energy (MI, Korea), and the Fundamental Research Program of the Korea Institute of Materials Science (KIMS).

\section{Authors' contributions}

DH conducted the experiments, collected the data, and wrote the paper. YN, M and SS guided and supported this work and contributed with their expertise and advices to write a paper. All authors read and approved the final manuscript. 


\section{Competing interests}

TThe authors declare that they have no competing interests.

\section{Author details \\ 'Department of Materials Engineering and Convergence Technology, ReCAPT, Gyeongsang National University, Jinju 52828, South Korea. 2Department of Materials Processing, Korea Institute of Materials Science, Changwon 51508, South Korea. ${ }^{3}$ Department of Mechanical Engineering, Oita University, Oita 870-1192, Japan.}

\section{Received: 5 August 2016 Accepted: 12 December 2016} Published online: 04 January 2017

\section{References}

Andrade, A., Morcelli, A., \& Lobo, R. (2010). Deformation and fracture of an alpha/ beta titanium alloy. Revista Matéria, 15(2), 364-370. doi:10.1590/S151770762010000200038.

ASTM Standard E466. (2002). Standard practice for conduction force controlled constant amplitude axial fatigue test of metallic materials. Annual Book of ASTM Standards, 03.01. Philadelphia: American Society for Testing and Materials.

ASTM Standard E647. (2002). Standard test method for measurement of fatigue crack growth rates. Annual Book of ASTM Standards, 03.01. Philadelphia: American Society for Testing and Materials.

Bania, P. J., Bidwell, L. R., Hall, J. A., Eylon, D., \& Chakrabarti, A. K. (1982). Fracture microstructure relationships in titanium alloys. In J. C. Williams \& A. F. Belov (Eds.), Titanium and titanium alloys, scientific and technological aspects (Vol. 1, p. 663). New York: Plenum Press.

Borisova, E. A., Shashenkova, I. I., Krivko, A. I., \& Barasheva, T. V. (1975). Vacuum annealing of titanium alloys. Met Sci Heat Treat, 17(4), 313-316. doi:10.1007/BF00663392.

Bowen, A. W., \& Stubbington, C. A. (1973). The effect of $a+\beta$ working on the fatigue and tensile properties of Ti-6Al-4V bars. In R. I. Jaffee \& H. M. Burte (Eds.), Titanium science and technology (p. 2097). New York: Plenum Press.

Campbell, F. (2008). Elements of metallurgy and engineering alloys. Ohio: ASM International.

Campbell, F. C., Jr. (2011). Manufacturing technology for aerospace structural materials. Amsterdam: Elsevier.

Chandler, H. (1996). Heat treater's guide: practices and procedures for nonferrous alloys. Ohio: ASM International.

Davis, J. R. (1995). ASM specialty handbook: tool materials. Ohio: ASM International.

Demulsant, X., \& Mendez, J. (1995). Microstructural effects on small fatigue crack initiation and growth in Ti6A14V alloys. Fatigue Fract Eng Mater Struct, 18, 1483-1497. doi:10.1111/j.1460-2695.1995.tb00870.x.

Donachie, M. J. (2000). Titanium: a technical guide (2nd ed.). United States of America: ASM International, Ohio.

Eylon, D., \& Pierce, C. M. (1976). Effect of microstructure on notch fatigue properties of Ti-6Al-4 V. Metall Mater Trans A, 7A, 111-121. doi:10.1007/ BF02644046.

Ezugwu, E. O., \& Wang, Z. M. (1997). Titanium alloys and their machinability-a review. J Mater Process Tech, 68, 262-274. doi:10.1016/S0924-0136(96)00030-1.

Froes, F. H. (2015). Titanium: physical metallurgy, processing and applications. Ohio: ASM International.

Gammon, L. M., Briggs, R. D., Packard, J. M., Batson, K. W., Boyer, R., \& Domby, C. W. (1985). Metallography and microstructures Vol 9. Ohio: ASM International.

Halliday, M. D., \& Beevers, C. J. (1981). Some aspects of fatigue crack closure in two contrasting titanium alloys. J Test Eval, 9, 195-201. doi:10.1520/JTE11227J.

Hicks, M. A., Jeal, R. H., \& Beevers, C. J. (1983). Slow fatigue crack growth and threshold behaviour in IMI 685. Fatigue Fract Eng Mater Struct, 6, 51-65. doi: 10.1111/j.1460-2695.1983.tb01138.x.

Hines, J. A., \& Lütjering, G. (1999). Propagation of microcracks at stress amplitudes below the conventional fatigue limit in Ti-6Al-4 V. Fatigue Fract Eng Mater Struct, 22, 657-665. doi:10.1046/j.1460-2695.1999.t01-1-00217.x

Inagaki, I., Takechi, T., Shirail, Y., \& Ariyasu, N. (2014). Application and features of titanium for the aerospace industry. Nippon Steel \& Sumitomo Metal Technical Report, 106, 22-27.

Ivasishin, O. M., Semiatin, S. L., Markovsky, P. E., Shevchenko, S. V., \& Ulshin, S. V. (2002). Grain growth and texture evolution in Ti-6Al-4 V during beta annealing under continuous heating conditions. Mater Sci Eng, A337, 88-96. doi:10.1016/S0921-5093(01)01990-6.

Jeong, D. H, Lee, S. G. Jang, W. K. Choi, J. K, Kim, Y. J \& Kim, S. S. (2013). Cryogenic S-N fatigue and fatigue crack propagation behaviors of high manganese austenitic steels. Metall Mater Trans A, 44A, 4601-4612. doi:10. 1007/s11661-013-1809-5.

Jeong, D. H., Choi, M. J., Baik, S. I., Lee, H. C., \& Kim, S. S. (2014). Effect of service exposure on fatigue crack propagation of Inconel 718 Turbine Disc Material at elevated temperatures. Mater Charact, 95, 232-244. doi:10.1016/j.matchar.2014.06.022.

Jeong, D. H., Lee, S. G., Seo, I. S., Yoo, J. Y., \& Kim, S. S. (2015a). Fatigue crack propagation behavior of Fe24Mn steel weld at 298 and $110 \mathrm{~K}$. Met Mater Int, 21(1), 22-30. doi:10.1007/s12540-015-1004-X.

Jeong, D. H., Lee, S. G., Seo, I. S., Yoo, J. Y., \& Kim, S. S. (2015b). Effect of applied potential on fatigue crack propagation behavior of Fe24Mn steel in seawater. Met Mater Int, 21(1), 14-21. doi:10.1007/s12540-015-1003-y.

Jeong, D. H., Sung, H. K., Kwon, Y. N., \& Kim, S. S. (2016a). Effect of superplastic forming exposure on tensile and S-N fatigue behavior of Ti64 alloy. Met Mater Int, 22(4), 594-600. doi:10.1007/s12540-016-6041-6.

Jeong, D. H., Sung H. K., Kwon, Y. N., \& Kim, S. S. (2016). Effect of superplastic forming exposure on fatigue crack propagation behavior of Ti-6Al-4V alloy. Met Mater Int, accepted. doi: 10.1007/s12540-016-6075-9

Jung, D. H., Kwon, J. K., Woo, N. S., Kim, Y. J., Goto, M., \& Kim, S. S. (2014). S-N fatigue and fatigue crack propagation behaviors of $\mathrm{X} 80$ steel at room and low temperatures. Metall Mater Trans A, 45A, 654-662. doi:10.1007/s11661-013-2012-4.

Kaminaka, H., Abe, M., Matsumoto, S., Kimura, K., \& Kamio, H. (2014). Characteristics and applications of high corrosion resistant titanium alloys. Nippon Steel \& Sumitomo Metal Technical Report, 106, 34-40.

Kim, Y. J., Kwon, J. K., Lee, H. J., Jang, W. K., Choi, J. K., \& Kim, S. S. (2011). Effect of microstructure on fatigue crack propagation and $\mathrm{S}-\mathrm{N}$ fatigue behaviors of TMCP steels with yield strengths of approximately $450 \mathrm{MPa}$. Metall Mater Trans A, 42A, 986-999. doi:10.1007/s11661-010-0577-8.

Kim, S. S., Kwon, J. K., Kim, Y. J., Jang, W. K., Lee, S. G., \& Choi, J. K. (2013). Factors influencing fatigue crack propagation behavior of austenitic steels. Mel Mater Int, 19(4), 1-8. doi:10.1007/s12540-013-4007-5.

Lucas, J. J., \& Konieczny, P. P. (1971). Relationship between alpha grain size and crack initiation fatigue strength in Ti-6Al-4 V. Metall Mater Trans A, 2A, 911 912. doi:10.1007/BF02662756.

Lütjering, G. (1998). Influence of processing on microstructure and mechanical properties of $(\alpha+\beta)$ titanium alloys. Mater Sci Eng, A243, 32-45. doi:10.1016/ S0921-5093(97)00778-8.

Lütjering, G., \& Williams, J. C. (2013). Titanium. Berlin: Springer Science \& Business Media.

Morita, T., Hatsuoka, K., lizuka, T., \& Kawasaki, K. (2005). Strengthening of Ti-6Al$4 \mathrm{~V}$ alloy by short-time duplex heat treatment. Mater Trans, 46(7), 1681-1686. doi:10.2320/matertrans.46.1681.

Mrazova, M. (2013). Advanced composite materials of the future in aerospace industry. Incas Bulletin, 5(3), 139-150. doi:10.13111/2066-8201.2013.5.3.14.

Nicholas, T. (2006). High cycle fatigue: a mechanics of materials perspective. Amsterdam: Elsevier.

Rajan, T. V., Sharma, C. P., \& Sharma, A. (2011). Heat treatment: principles and techniques. New Delhi: PHI Learning Pvt. Ltd.

Ruppen, J., Bhowal, P., Eylon, D., \& McEvily, A. J. (1979). On the process of subsurface fatigue crack initiation in Ti-6Al-4V. In J. Fong (Ed.), Fatique mechanisms, ASTM STP 675 (p. 47). Philadelphia: American Society for Testing and Materials.

Semiatin, S. L., Knisley, S. L., Fagin, P. N., Zhang, F., \& Barker, D. R. (2003). Microstructure evolution during alpha-beta heat treatment of Ti-6Al-4 V. Metall Mater Trans A, 34A, 2377-2386. doi:10.1007/s11661-003-0300-0.

Starke, E. A., \& Williams, J. C. (1989). Microstructure and the farcture mechanics of fatigue crack propagation. In R. P. Wei \& R. P. Gangloff (Eds.), Fracture mechanics: perspectives and directions, ASTM STP1020 (p. 184). Philadelphia: American Society for Testing and Materials.

Sung, H. K., Jeong, D. H., Park, T. D., Lee, J. S. \& Kim, S. S. (2016). S-N fatigue behavior of Fe25Mn steel and its weld at 298 and $110 \mathrm{~K}$. Met Mater Int, accepted. doi: 10.1007/s12540-016-6108-4

Suresh, S. (1983). Crack deflection: implications for the growth of long and short fatigue cracks. Metall Mater Trans A, 14A, 2375-2385. doi:10.1007/BF02663313.

Suresh, S. (1985). Fatigue crack deflection and fracture surface contact: micromechanical models. Metall Mater Trans A, 16A, 249-260. doi:10.1007/BF02815306.

Suresh, S., \& Ritchie, R. O. (1982). A geometric model for fatigue crack closure induced by fracture surface morphology. Metall Mater Trans A, 13A, 1627-1631. doi:10.1007/BF02644803.

Venkatesh, B. D., Chen, D. L., \& Bhole, S. D. (2009). Effect of heat treatment on mechanical properties of Ti-6Al-4 V ELI alloy. Mater Sci Eng, A506, 117-124. doi:10.1016/j.msea.2008.11.018. 
Wanhill, R., \& Barter, S. (2011). Fatigue of beta processed and beta heat-treated titanium alloys. Berlin: Springer Science \& Business Media.

Welsch, G., Boyer, R., \& Collings, E. W. (1993). Materials properties handbook: titanium alloys. Ohio: ASM International.

Yoder, G. R., Cooley, L. A., \& Crooker, T. W. (1976). A micromechanistic interpretation of cyclic crack-growth behavior in a beta-annealed Ti-6Al-4V alloy. Washington: US Naval Research Lab.

Ziaja, W., Sieniawski, J., Kubiak, K., \& Motyka, M. (2001). Fatigue and microstructure of two phase titanium alloys. Inżynieria Materiałowa, 22(3), 981-985. doi:10.1016/50921-5093(97)00778-8.

\section{Submit your manuscript to a SpringerOpen ${ }^{\circ}$ journal and benefit from:}

- Convenient online submission

- Rigorous peer review

- Immediate publication on acceptance

Open access: articles freely available online

- High visibility within the field

- Retaining the copyright to your article

Submit your next manuscript at $\gg$ springeropen.com 